\title{
Illuminating Inscriptions
}

Yaakov Medan

In a series of lectures given at Yeshivat Har Hamor, the founder of the yeshiva Rabbi Tsvi Israel Tau harshly criticized religious teachers colleges for integrating academic material into their religious studies courses. ${ }^{1}$ His remarks were summarized in a pamphlet published by a student at the yeshiva, Netanel Binyamin Elyashiv. ${ }^{2}$ The opinions expressed in the pamphlet raised important questions about the direction of the religious colleges and their associated yeshivot (and, perhaps, primarily my yeshiva, Har Etzion). ${ }^{3}$ In this article I will address one of the issues raised in the pamphlet, the use of non-Jewish historical sources from the biblical period to deepen and expand our understanding of the Bible.

In principle, I would like to state that I agree with Rabbi Tau that the integration of secular ideas and sources into the study of religious texts has the potential to decrease students' reverence for the sanctity of the religious sources. This clear and present danger requires us all to engage in deep soul-searching, and to place clear boundaries between the permissible and the forbidden when we begin to mix the holy with the profane. It obligates us all to ask ourselves honestly: Are we doing enough to instill a love for Torah within ourselves and our students? Are we fighting the apathy toward it found at times within the religious public in general, and among young students in particular?

However, it sometimes appears that in his justifiable anger at those who are violating what is sacred, Rabbi Tau leans toward outright negation of all assistance from the secular academic world. This attitude brings to mind the story of the rabbinical student who refused food altogether for fear that he would inadvertently eat something forbidden. Rabbi Tau's words would imply that the religious world, which by its very nature is meant to be built on the foundation of the secular world, will have to stand on its own without the secular world supporting it. ${ }^{4}$

For example, Rabbi Tau rejects the use of Canaanite poetry as an aid to understanding the Psalms. ${ }^{5}$ If his intention is that the study of the psalms 
should not be restricted to this comparative approach, or that a comparative approach should not preclude the examination of the sacred fundamental meaning of the psalms, I support his position without reservation. However, his words could be taken to mean that he rejects the use of Canaanite literature even as an aid to understanding a difficult word or literary motif. It is difficult for me to accept this position.

Moreover, Rabbi Tau himself affirms that, in general, he does not object to secular studies, despite the considerable risk that the study of the physical sciences (especially of such subjects as evolution, the age of the universe, and human origins among others) will weaken religious faith. ${ }^{6}$ It would appear that Rabbi Tau understands that the study of the physical sciences is necessary both for the survival of modern civilization and the integration of religious Jews within it. $\mathrm{He}$ relies upon the ability of the beit midrash to answer the challenges raised by the physical sciences. If so, why should we not make use of developments in the academic study of literature, history, and archeology in the study of our sacred texts?!

Rabbi Tau declares elsewhere: "Far be it from us to examine the Torah and the prophets by secular, historical, and literary criteria." ${ }^{7}$ With regard to secular criteria, his words are doubtless correct. However, with regard to historical and literary criteria, his words are correct only if the word "alone" is added to them. In other words, we must not analyze the Torah and Prophets by means of historical and literary criteria alone, without attempting to also understand their sacred meaning. Without this correction, his words are obtuse and unintelligible, and appear to contradict the meaning of Rav Kook's letter 146, cited by Rabbi Tau in support of his opinion.

This particular point is the subject of this article: the need to rely on academic analysis of ancient non-Jewish sources in order to understand the sacred meaning of our sources. Given the scope of the current forum, I will confine my discussion to three examples (out of many), and even these will be discussed concisely, without the detailed analysis they deserve. ${ }^{8}$ Many ancient sources assist in literary interpretation and, in particular, linguistic interpretation of difficult words and concepts in the Bible. However, this article will focus on examples of historical interpretation.

\section{The Status of Shechem and its Environs at the Time of Joshua's Conquest of Canaan}

On the plains of Moab, ${ }^{9}$ Moses instructed the People of Israel that immediately after crossing the Jordan River they must set up large stones on Mount Ebal, inscribe upon them the words of the Torah, and build an altar. ${ }^{10}$ As it 
happened, Joshua conquered Jericho, Ai, and Bethel before he was able to build the altar on Mount Ebal. ${ }^{11}$

Surprisingly, the biblical narrative does not mention Joshua's struggle with the enemy in the area of Mount Ebal, the inhabitants of Shechem and its vicinity, from whom, or so it would seem, the land would have to be conquered in order to perform the covenantal ceremony. From reading the biblical narrative on its own, it is not clear how Joshua and the people went from Ai to Shechem without fighting and conquering the fortified cities along the way, as well as Shechem itself. In addition, the list of the thirty-one kings conquered by Joshua (Josh. 12) does not include the king of Shechem or the known cities in its environs, even though this area is the heart of the western part of the Land of Israel.

According to the biblical narrative, after the covenantal ceremony on Mount Ebal, the Gibeonites came to make a pact with Joshua. This episode also raises questions, the most important of which is why the Gibeonites, out of all the local nations, decided to make peace with Joshua?

Archeological excavations in the last few decades near Gibeon and the foothills of Shechem have uncovered Israelite settlements that predate the Exodus from Egypt. They are apparently connected to the early immigration of the tribe of Ephraim, which began, at the latest, two generations after the arrival of the children of Jacob in Egypt. Some of the events of the pre-Exodus immigration of the descendants of Ephraim are described in Chronicles:

The sons of Ephraim: Shuthelah, his son Bered, his son Tahath, his son Eleadah, his son Tahath, his son Zabad, his son Shuthelah, also Ezer and Elead. The men of Gath, born in the land, killed them because they had gone down to take their cattle. And Ephraim their father mourned many days, and his brothers came to comfort him. He cohabited with his wife, who conceived and bore a son; and she named him Beriah, because it occurred when there was misfortune in his house. His daughter was Sheerah, who built both Lower and Upper Beth-horon, and Uzzensheerah (1 Chron. 7:20-24).

Was the proximity of Gibeon to the Israelite settlements of Upper and Lower Beit Horon, built by the children of Ephraim, connected to the request of the Gibeonites to make a pact with Joshua? The biblical narrative does not elucidate this point.

At the end of his life, in Shechem, Joshua renewed the covenant between God and the People of Israel. Before the sealing of the covenant he proposed 
to the people that they not worship the Lord, because "He is a jealous God" (Josh. 24:19), but instead choose for themselves another "god": "Or, if you are loath to serve the Lord, choose this day which ones you are going to servethe gods that your forefathers served beyond the Euphrates, or those of the Amorites in whose land you are settled; but I and my household will serve the Lord" (24:16).

This suggestion seems incredible. After the covenants on Mount Sinai, in the plains of Moab, and Mount Ebal, and the conquest of the land, was it still possible for the People of Israel to terminate their agreement with God?! Even if it were possible, why did Joshua mention, as alternative deities, the gods their ancestors worshipped on the other side of the Jordan, rather than the Egyptian gods with whom they were now more familiar?

I will put aside for now the questions I have raised about the book of Joshua, questions hardly addressed by the classical commentators, and turn to another subject. The book of Judges relates that the "citizens of Shechem" agreed that Abimelech would rule over them, among other reasons because his father Gideon married a woman from Shechem (Judg. 9:2). However, later on a "spirit of discord" developed between Abimelech and the "citizens of Shechem" who betrayed him and planted ambushes in order to rob him (9:23).

The identity of the "citizens of Shechem" is not clear from the verses. Were they Jews or Canaanites? The temple of the people of Shechem is referred to once as the "temple of Baal-berith" (9:4) and another time as the "temple of El-berith" (9:46). Was this a temple of the Lord, who made a covenant with the People of Israel in Shechem, Gerizim, and Ebal, or a temple for the worship of Baal?

The identity of the "citizens of Shechem" is important because it indicates whether the concubine (or maidservant) of Gideon, the mother of Abimelech, was an Israelite or a gentile. Abimelech, who inherited the status and role of his father as a judge of Israel, saw himself, apparently, as a member of the People of Israel. However, the biblical narrative portrays the "citizens of Shechem" going at their harvest time to "the temple of their god" (9:27) and their leader, Gaal son of Ebed, calling to them to serve "the men of Hamor, the father of Shechem" (9:28). These are not characteristic behaviors of the People of Israel.

Analyses of the verses and the use of the accepted exegetical methods yield cogent answers to some of the questions that I have raised. For other questions, 
however, only partial answers, if any, can be found. This is a situation in which the philological study of ancient documents can come to the assistance of the Bible student.

Amarna is a poor village built on the ruins of the ancient city of Akhetaten, extending from Luxor along the eastern Nile. In 1887, clay tablets dating from the fourteenth century BCE were accidently discovered there. These were part of the ancillary archives of Pharaoh Akhenaten (Amenhotep IV). In 1891, the "Records Office," where many documents were discovered, was uncovered there. The documents that were retrieved and translated, referred to today as the "Amarna letters," include many letters sent to the king of Egypt from kings and various personages in Canaan.

In one series of letters, Abdi-Heba, the ruler of Jerusalem, complains to Amenhotep that many of the surrounding inhabitants are betraying him and collaborating with the Apiru tribes invading Canaan. There is no scholarly consensus on the question of whether the Apiru (or Habiru) tribes can be identified with the Hebrews, the People of Israel under the leadership of Joshua, who began the period of their conquest and settlement at this time. ${ }^{12}$ In the context of this article, it is sufficient to note that there is a strong basis for assuming that the Apiru tribes can in fact be identified with the Israelites. ${ }^{13}$

In the letter catalogued as "Amarna 287," the king of Jerusalem complains about "the deed of the sons of Lab'ayu, [the king of Shechem] who have given the land of the king to the "Apiru."14 Similarly, in "Amarna 289" he asks: "Are we to act like Lab'ayu when he was giving the land of Šakmu to the Hapiru?"15 In letter 290 he relates that "the land of the king deserted to the Hapiru," and in the same letter also accuses Beit Horon (the city built by the daughter of Beriah the son of Ephraim) of desertion. ${ }^{16}$

From these documents it would seem possible to conclude that from the time that the tribes of Israel appeared in the Land of Israel there was a special relationship between them and the inhabitants of Shechem and its vicinity.

Genesis 35:5 describes Jacob's relations with the inhabitants of the land after Simeon and Levi killed the people of Shechem: "As they set out, a terror from God fell on the cities round about, so that they did not pursue the sons of Jacob." An external midrash, called Ve-Yisu (on the basis of its first word), discusses in depth the meaning of this verse. ${ }^{17}$ The midrash explains that the fear of the local nations was not unreasonable; it was the result of the huge defeat suffered by the cities surrounding Shechem at the hands of Jacob and his family. According to the midrash, these cities went to war against Jacob and his sons; the latter won and conquered all of the land surrounding Shechem, 
including most of Samaria from Bethel until south of Mount Gilboa. The midrash goes on to explain that at the end of his life Jacob spoke to Joseph about this expansive area of land: "And now, I assign to you one portion more than to your brothers, which I wrested from the Amorites with my sword and bow" (Gen. 48:22).

With the information I have compiled so far from the Bible, the midrash, and the Amarna letters, it is possible to construct the following scenario:

As a result of the altercation between the family of Jacob and the inhabitants of Shechem over the rape of Dinah, a war broke out involving all of Samaria, Shechem, and its environs. In this war, Jacob and his family defeated the Hivites, the subjects of Hamor the Hivite, the prince of Shechem. ${ }^{18}$ They also conquered most of Samaria and settled it with their people-their followers, and the vanquished peoples who agreed to accept the authority of Jacob's family, and perhaps even its religious faith. This sequence of events explains why even after Jacob's family moved to Hebron, his sons grazed their father's flocks in the area of Shechem as far as Dothan.

When Jacob's family went to Egypt, Canaanites and converts who had come from Haran with Jacob, and perhaps even earlier with Abraham, remained in the area of Shechem. Although these people would have maintained aspects of the Patriarchs' religious faith, it can be assumed that these beliefs became corrupted by the influence of the surrounding Canaanite culture over the course of the following two centuries.

When the children of Ephraim left Egypt and came to the Land of Israel, ${ }^{19}$ before the "official" Exodus, ${ }^{20}$ the natural place for them to choose to settle in was the area that had belonged to their forefathers-Shechem and the surrounding area. They returned to live with the Hivites who in the past had been the dependents of Abraham and of Jacob's family, and had intermingled with them.

After the Exodus from Egypt, the great miracles performed for the People of Israel in Egypt and in the desert were known to all the inhabitants of the land, as we learn from the words of Rahab the harlot (Josh. 2:9-11). The Hivites (and among them the descendants of Ephraim) were prepared to make peace with the Israelites and to accept their authority and their religious beliefs. Gibeon was one of the Hivite cities (Josh. 9:7), and thus its inhabitants seized the opportunity to make peace with Joshua. It can be assumed that the people of Beit Horon, the city of Beriah son of Ephraim, adjacent to Hebron, also cooperated with the Israelites, as did the king of Shechem and all the surrounding cities (whose inhabitants were Hivite, or the descendants of those 
who came from Haran). The king of Jerusalem was angered by this "treason," as is revealed in his letters to the king of Egypt discussed above. This is compatible with Joshua 10:1-5, which relates that the king of Jerusalem was the head of the coalition of the five kings fighting against Gibeon because it had made peace with the Israelites.

It can be assumed that, even before they crossed the Jordan, the Israelites were aware of the amity of the people of the Shechem area, and, if so, Joshua knew that he would not find it difficult to perform the covenantal ceremony on Mount Ebal even before the area was conquered. For this reason, the Israelites fought no battles in the entire region of Shechem!

At the end of the conquests under his leadership, Joshua gathered the people to make another covenant with God (Josh. 24; see above). As opposed to the covenant at Sinai and at Mount Ebal, this covenant included many non-Jews among the population of greater Shechem who had accepted the faith of the house of Abraham already in the days of the Patriarchs. Now they were asked to reaffirm this faith. Because they were not a part of the People of Israel, Joshua gave them the option of not entering the covenant. He suggested that they continue to worship the gods from beyond the river Jordan (from whence they had come with Abraham), or the gods of the Amorites (near their current place of residence) and thus to be considered Canaanites (with all the implications regarding their continued residence in the land). Joshua did not suggest that they worship Egyptian gods, because he knew that they were not familiar with them. If the inhabitants of the Shechem region were to return to the Amorite gods, the Israelites in the area who so chose, would be able (illicitly, of course!) to join them. In the end the people of the Shechem region refused Joshua's offer, and joined the chorus of the entire People of Israel pledging their allegiance to the Lord.

In the days of Abimelech, after the worship of God weakened over the course of many generations during the period of the Judges, the temple of the Hivites residing in Shechem transformed from "Beit El-berith" to "Beit Baal-berith." The situation reached the point that Gaal the son of Eved and his people no longer saw themselves as converts, but as the people of Hamor the father of Shechem.

The sequence of events that I have proposed requires additional clarifications and proofs. In general, there is no certain evidence connecting the Amarna letters of the king of Jerusalem to Joshua's conquests. Nonetheless, I have proposed a plausible scenario that resolves the difficulties raised by the simple meaning of the biblical text. This scenario is based in part on non-Jewish sources from the biblical period. 


\section{The Power of Ahab's Army}

The sages describe Ahab as the ruler of the world:

Rabbi Elazar said in the name of Rabbi Haninah: There are two hundred and fifty-two regions in the world and David ruled all of them, as it is written, "David became famous throughout the lands" (1 Chron. 14:17); Solomon ruled all of them, as it is written, "Solomon's rule extended over all the kingdoms" (1 Kings 5:1); Ahab ruled all of them as it is written, "As the Lord your God lives, there is no nation or kingdom to which my lord has not sent to look for you and when they said, $\mathrm{He}$ is not here,' he made that kingdom or nation swear that you could not be found" (1 Kings 18:10). Can a man force people to swear an oath in a place that he does not rule? ${ }^{21}$

The verses cited by the sages as proof of the size of Ahab's kingdom are corroborated by another verse that mentions the many captives at Ahab's court: "So he mustered the aides of the provincial governors, 232 strong" (1 Kings 20:15). It was a diplomatic practice for a vassal kingdom to send young men to the court of the sovereign kingdom as a pledge of its loyalty. The more than 200 diplomatic aides held as security pledges testify to the ascendency of Ahab's kingdom in the period described in this chapter.

However, this political power does not correlate with the small size and weakness of Ahab's army during the war described there, the first war with Ben-hadad, the king of Aram: "So he mustered the aides of the provincial governors, 232 strong, and then he mustered all the troops-all the Israelitesseven thousand strong" (20:15). The same situation prevailed in the second war: "Now the Israelites had been mustered and provisioned, and they went out against them; but when the Israelites encamped against them, they looked like two flocks of goats, while the Arameans covered the land" (20:27).

The midrash cited above suggests two possible ways of reconciling the contradiction: "Rabbi Levi and the Rabbis: Rabbi Levi said that they died in a famine in the time of Elijah and the Rabbis said that Ben-hadad came and took them." On first sight, both opinions cited in the midrash require explanation. Rabbi Levi explains that a great multitude died in a famine. However, a simple reading of the text indicates that the prophecy relating to the weakening of Ahab's military power was given later, after rain had fallen at the end of the great famine: "Whoever escapes the sword of Hazael shall be slain by Jehu, 
and whoever escapes the sword of Jehu shall be slain by Elisha. I will leave in Israel only seven thousand-every knee that has not knelt to Baal and every mouth that has not kissed him" (19:17-18).22 The explanation of the Rabbis that Ben-hadad had taken Ahab's army is also not clear. If Ahab was strong, how was Ben-hadad able to strike him?! I have not found an answer to these questions in the literature found in the beit midrash.

In the nineteenth century, the annals of the Assyrian kings (the records of royal journeys) were discovered in the ruins of temples and royal palaces in the Assyrian capital cities. Many of these annals were inscribed on huge statues in the form of winged bulls, some in reliefs or engravings on large stones, and others on clay cylinders or prisms. ${ }^{23}$ The inscriptions were written in cuneiform, and it took roughly a century to decipher them. ${ }^{24}$ Despite their limited reliability, these writings shed light on the wars described in the Bible.

The annals relate that Shalmaneser III, the king of Assyria (reigned 858-824 BCE), as part of his attempts to expand the borders of the Assyrian empire, fought the southern coalition of the twelve kings of the coast in battle at Karkar next to Hamath (Hama). The leader of the coalition was Hadadezer, the king of Aram, with an army of 1,200 chariots, 1,200 riders and horsemen, and 20,000 foot soldiers. He was joined by Irhuleni the king of Hamath with seven hundred chariots and "Ahabu ha-Yisraeli" (Ahab, the king of Israel) with two thousand chariots and ten thousand infantrymen. The coalition armies apparently succeeded in deterring Shalmaneser, and the Assyrian invasion was halted for many years, until the time of Menahem son of Gadi, the king of Samaria. ${ }^{25}$ The annals relate that despite their ultimate victory, the armies of the coalition sustained serious causalities at the hands of the Assyrians.

It can be assumed that Ahab's army, because it provided most of the chariots in the coalition army (as described in the annals), entered the battle first, and thus bore the brunt of the Assyrian onslaught and, in effect, repelled it. Ahab's primary ally, Hadadezer (Ben-hadad), the king of Aram, was a double winner: the king of Assyria retreated north, and Ahab, a temporary ally but permanent rival for regional hegemony, suffered the greatest loses and his army was diminished. In the war described in 1 Kings 20, Ben-hadad took advantage of this situation and demanded the now weakened Ahab to submit to a demeaning state of vassalage to Aram. 
The prophecy received by Elijah at Horeb hints at this punishment at the hands of the Assyrian king: "I will leave in Israel only seven thousand" (1 Kings 19:18). In fact, Ahab only recruited 7,000 soldiers for the war against Aramean servitude (20:15). Nonetheless, in the end, he twice defeated the king of Aram by miraculous means.

The reader is probably wondering why an event as important to the history of the kingdom of Ahab as a war against Assyria and a victory achieved at a heavy price would be omitted from the biblical narrative. One possible answer is that the war was intentionally omitted because the victory was attained by means of an alliance between Ahab and Ben-hadad, the king of Aram, against whom the prophet rails $(20: 34-43) .^{26}$

Once again, I have used ancient writings to understand the biblical text. In this case, to explain how Ahab was transformed from a powerful monarch with regional supremacy to a king unable to recruit an army adequate to defend himself and his kingdom!

\section{The War of Jehoshaphat and Jehoram against Mesha, King of Moab}

Now King Mesha of Moab was a sheep breeder; and he used to pay as tribute to the king of Israel a hundred thousand lambs and the wool of a hundred thousand rams. But when Ahab died, the king of Moab rebelled against the king of Israel. So King Jehoram promptly set out from Samaria and mustered all Israel At the same time, he sent this message to King Jehoshaphat of Judah: "The king of Moab has rebelled against me; will you come with me to make war on Moab?" He replied, "I will go. I will do what you do: my troops shall be your troops, my horses shall be your horses" (2 Kings 3:4-7).

And he said, "Thus said the Lord: This wadi shall be full of pools. For thus said the Lord: You shall see no wind, you shall see no rain, and yet the wadi shall be filled with water; and you and your cattle and your pack animals shall drink. And this is but a slight thing in the sight of the Lord, for He will also deliver Moab into your hands. You shall conquer every fortified town and every splendid city; you shall fell every good tree and stop up all wells of water; and every fertile field you shall ruin with stones." And in the morning, when it was time to present the meal offering, water suddenly came from the direction of Edom and the land was covered by the water $(16-20)$. 
According to these verses, the war of Moab against Israel and Judah began when Mesha, the king of Moab, rebelled against the king of Israel and stopped paying the wool tax to which he had agreed already in the time of Ahab. ${ }^{27}$ At this point the reader may wonder: Why was this "war of the wool tax" so important that Elisha prophesized about the revealed miracles that would be performed for Israel during the war, despite their sin of idolatry?

Furthermore, according to the simple meaning of the text, in these verses the prophet declares a temporary suspension of a prohibition in the Torah, and commands the destruction of the fruit-bearing trees of Moab during the war. ${ }^{28}$ Is the failure to pay taxes to the king of Israel really a sufficient cause for overriding this prohibition?

In 1868 the "Mesha Stele" or "Moabite stone" was discovered in Dibon (Dhiban), north of the Arnon River located today in Jordan. It was almost destroyed by Bedouin in the course of an argument, but with the assistance of the French researcher Charles Simon Clermont-Ganneau, then a member of the staff of the French Consulate in Jerusalem, it was reconstructed and is now in the Louvre Museum in Paris. A replica is in the collection of the Rockefeller Museum in Jerusalem. An examination of the inscription on the stone reveals that the words "the king of Moab rebelled against the king of Israel" (2 Kings 3:5) do not refer to the non-payment of the tax alone, but to a much more serious matter.

The first line of the inscription reads: "I am Mesha, son of Chemosh [...], king of Moab, the Dibonite." In line 14, Mesha describes how he went as an emissary of Chemosh his god to fight Israel ("And Chemosh said to me, Go, take Nebo from Israel!"). In lines 16-17, he describes how in one battle he killed 7,000 men, women, and children for the glory of his god, AshtarChemosh, and took the vessels of the temple of the Lord: "And slaying all, 7,000 men, boys, women, girls and maid-servants, for I had devoted them to destruction for (the god) Ashtar-Chemosh. And I took from there the [...] of Yahweh, dragging them before Chemosh." (In the inscription, the YHVH name of God is used.) In lines 25-26, Mesha describes how he used the Jewish war captives as slave labor in his land. ${ }^{29}$

The perceived desecration of the Lord's name in Chemosh's victory over the Lord, and Mesha's extreme cruelty toward he people of Gad, prompted Elisha to go to war against the army of Jehoram. It also led to his prophecy about the revealed miracle that was supposed to bring military victory and the complete destruction of Moab. These factors also led to the emergency ruling 
temporarily suspending the Torah's prohibition of the destruction of fruit trees, as an expression of God's vengeance against Mesha (and Chemosh, his god) for his deeds. Again, an ancient inscription from biblical times has helped to explain a perplexing passage in the Bible.

It is possible that information derived from the Mesha Stele can also help us understand an unclear passage in Isaiah:

The "Moab" Pronouncement.

Ah, in the night Ar was sacked,

Moab was ruined;

$\mathrm{Ah}$, in the night Kir was sacked,

Moab was ruined.

He went up to the temple to weep,

Dibon [went] to the outdoor shrines.

Over Nebo and Medeba

Moab is wailing;

On every head is baldness,

Every beard is shorn.

In its streets, they are girt with sackcloth;

On its roofs, in its squares,

Everyone is wailing,

Streaming with tears.

Heshbon and Elealeh cry out,

Their voice carries to Jahaz

Therefore,

The shock troops of Moab shout,

His body is convulsed.

My heart cries out for Moab-

His fugitives flee down to Zoar,

To Eglath-shelishiyah.

For the ascent of Luhith

They ascend with weeping;

On the road to Horonaim

They raise a cry of anguish. 
Ah, the waters of Nimrim

Are become a desolation;

The grass is sear, the herbage is gone,

Vegetation is vanished.

Therefore,

The gains they have made, and their stores,

They carry to the Wadi of Willows.

Ah, the cry has compassed

The country of Moab:

All the way to Eglaim her wailing,

Even at Beer-elim her wailing!

Ah, the waters of Dimon are full of blood

For I pour added [water] on Dimon;

I drench it—for Moab's refugees—With soil for its remnant

(Isa. 15)

We have heard of Moab's pride-

Most haughty is he-

Of his pride and haughtiness and arrogance,

And of the iniquity in him."

Ah, let Moab howl;

Let all in Moab howl!

For the raisin-cakes of Kir-hareseth

You shall moan most pitifully.

The vineyards of Heshbon are withered,

And the vines of Sibmah;

Their tendrils spread

To Baale-goiim,

And reached to Jazer,

And strayed to the desert;

Their shoots spread out

And crossed the sea. 
Therefore,

As I weep for Jazer,

So I weep for Sibmah's vines;

O Heshbon and Elealeh,

I drench you with my tears.

Ended are the shouts

Over your fig and grain harvests.

Rejoicing and gladness

Are gone from the farm land;

In the vineyards no shouting

Or cheering is heard.

No more does the treader

Tread wine in the presses-

The shouts have been silenced.

Therefore,

Like a lyre my heart moans for Moab,

And my very soul for Kir-heres. And when it has become apparent that Moab has gained nothing in the outdoor shrine, he shall come to pray in his temple-but to no avail.

That is the word that the Lord spoke concerning Moab long ago. And now the Lord has spoken: In three years, fixed like the years of a hired laborer, Moab's population, with all its huge multitude, shall shrink. Only a remnant shall be left, of no consequence. (16: 6-14)

This prophecy appears to contain allusions to the narrative of the Mesha Stele_-in particular, to place names such as Dibon, Nebo, Medeba, Jahaz, Horonaim, Kir Moab (which perhaps means Ir Moab, "the city of Moab") Kir-heres or Kir-hareseth-and it is possible that the prophet was familiar with the stele.

Moreover, the prophecy is filled with allusions to the pride of Moab, so blatantly expressed in the Mesha Steele by the continued repetition of the word "I." In addition, the inscription alludes to the victory banquets that Mesha held to celebrate his cruel subjugation of the Israelites living east of the Jordan. We may assume that at these celebrations the wine flowed freely, as is common at banquets, especially in the land of Moab, rich in vineyards. This sheds additional 
light on the curses which the prophet foretells will befall Moab: tears and wailing, and the silencing of cries of hedad, a phrase that served both as a cry of victory and as a call to set the rhythm while stomping grapes to make wine. ${ }^{30}$

It is possible that the prophecy in Isaiah was originally spoken by Elisha at the time of the war of revenge against Moab, as it is written in the prophecy: "That is the word that the Lord spoke concerning Moab long ago" (16:13). Isaiah added to it only the last line: "And now the Lord has spoken: In three years, fixed like the years of a hired laborer, Moab's population, with all its huge multitude, shall shrink. Only a remnant shall be left, of no consequence" (16:14). This prophecy was not fulfilled at the time of Mesha, for the reason given at the time of the war of Jehoram: "A great wrath came upon Israel, so they withdrew from him and went back to [their own] land" (2 Kings 3:27). Nonetheless, this final verse explains that the prophecy was not invalidated but would be fulfilled in the time of Hezekiah and was therefore repeated, at that time, by Isaiah.

Science, in all its branches, is a resource. It is similar to water, food, money, and other things that we use. Each of us, in the choices we make according to our system of belief, decides whether to use these resources for good or for evil, for faith or for heresy, to draw closer to holiness or to distance ourselves from it. The study of documents and ancient sources from the time of the Bible, or any other period, is not inherently different from other branches of science. If we are worthy, the use of academic research in Torah study will be an elixir of life, not a poison.

\section{Endnotes}

1. It is my understanding that Rabbi Tau prefers not to be referred to by the title Rosh Yeshivah and his wish must be respected.

2. Tsvi Israel Tau, Tzadik be-Emunato Yehyeh (Jerusalem: N. B. Elyashiv, 2002).

3. I will not refrain from stating that in my opinion the rabbi's opinions are worthy of a better organized and better written forum than the pamphlet in which they appear. I will not elaborate here.

4. The idea of the "two floors" appears in several places in the writings of Rav Abraham Isaac ha-Kohen Kook. See Iggrot ha-Ra'aya [The letters of Rav Kook] (Jerusalem: Mosad Harav Kook, 1985), 1:135; “Rosh Davar” 11 (Mussar ha-Kodesh), in Orot ha-Kodesh (Jerusalem: Mosad Harav Kook, 1964), 3:27, inter alia.

5. "U-Nishmat Mi Yatza Mimekh," in Tzadik be-Emunato Yehyeh, 32.

6. "Al Plishat Ha-Hol el ha-Kodesh," in Tzadik be-Emunato Yehyeh, 37.

7. "Ke-she-Niknasu Yivanim le-Heichal," in Tzadik be-Emunato Yehyeh, 47.

8. Rav Kook made salient points on this subject as well in his introduction to "Mussar Ha-Kodesh" mentioned above. See "Rosh Davar" 9, 26; 6, 24; 14, 31. 
9. This section is based on material that 1 learned in my youth from my teacher, Rabbi Yoel Bin Nun. However, I am unaware of his current position on these matters and the responsibility for the content is entirely my own.

10. Deut. 11:29-30; 27:2-8.

11. This is according to the peshat meaning of the verses in Joshua 8 , and the commentaries of Isaac Abravanel and the Malbim on these verses. The Babylonian Talmud, tractate Sotah 36a records a controversy among the sages of the Mishnah on the question of when the covenant was made. Rabbi Shimon was of the opinion that the People of Israel made the covenant on the day they crossed the Jordan. This can also be understood from the simple meaning of the Mishnah (Sotah 7:5) and the Tosefta (Sotah 8:7). See also the opinion of Rabbi Yehudah in the Jerusalem Talmud, tractate Sotah 7:3; Seder Olam Rabbah, 11. The opinion of Rabbi Ishmael is that the People of Israel arrived at Mount Ebal only after fourteen years of conquest and the division of the land, while Rabbi Elazar argues that in this context "Gerizim and Ebal" refer to two small slopes on the banks of the Jordan, not the hills near Shechem.

12. M. Greenberg, "H’bru (H'fru)_Ivrim" [Habiru [Apiru]—Hebrews], in Ha-Historia shel Am Yisrael [The history of the Jewish people], ed. Benjamin Mazar (Jerusalem: Am Oved, 1982), 2:95-102. Greenberg argues, in brief, on the basis of a previous, longer article, that the Apiru were the Israelites. Nadav Na'aman, in Ha-Historia shel Eretz Yisrael [The history of the Land of Israel], ed. Yaacov Shavit (Jerusalem: Keter, 1982), 1:233-240, rejected this approach and explained the verse in another way. My teacher Rabbi Yoel Bin Nun ("Ha Ivrim ve-Eretz ha-Ivrim" [The Hebrews and the land of the Hebrews], Megadim 15 [1992]: 9-26) took the best from both approaches to create a third approach.

13. The academic world is divided on the question of the relative chronologies of the Amarna documents and the Exodus. For the purposes of this article I have followed the opinion of Professor Immanuel Velikovsky and the many other scholars who agree with him. The more current opinion reverses the chronological order. The scope of this article does not allow me to explain these approaches in depth or my reasons for preferring one over the other. My opinions on the subject are not conclusive.

14. For a translation of the documents and their history see William L. Moran, ed. and trans., The Amarna Letters (Baltimore: Johns Hopkins University Press, 1992). The quote from letter 287 in on page 328 .

15. Ibid., 332-333.

16. Ibid., 334 .

17. This midrash appears also as "Milhemet Ya'akov u-Banav" [The war of Jacob and his sons], in Sefer Ha-Yasher, ed. Joseph Dan (Jerusalem: Mosad Bialik, 1986), 168-186.

18. See Gen. 34:2.

19. See the quotes above from Chron. See also Ps. 78:9-10, and the Jerusalem Targum (Targum Pseudo-Jonathan) to Ex. 13:17: "And so it was that when Pharaoh had freed the people, the Lord did not lead them by the way of the land of the Philistines, though that was near, for the Lord said, 'Lest the people be frightened by seeing their brethren who were killed in war' - two hundred thousand strong men of the tribe of Ephraim, who took shields, and lances, and other weapons, and went down to Gat to carry off the flocks of the Philistines. Because they transgressed against the decree of the Lord, and left Egypt three years before the end, they were delivered into the hand of the Philistines, who killed them. These are the dry bones which the word of the Lord restored to life through Ezekiel the prophet, in the valley of Dura. However, if they saw them, they would be afraid, and return to Egypt."

20. There are many midrashim on this subject. I will provide two examples. First from the Babylonian Talmud, tractate Sanhedrin 92b: "Now, who were they whom Ezekiel revived?- 
Rav said: 'They were the children of Ephraim, who counted to the end but erred, as it is written, "And the sons of Ephraim; Shuthelah, and Bared his son, and Tahath his son, and Eladah his son, and Tahath his son. And Zabad his son, and Shuthelah his son, and Ezzer, and Elead, whom the men of Gath that were born in that land slew" (1 Chron. 7:20-21), and "And Ephraim their father mourned many days, and his brethren came to comfort him" (7:22)." Secondly, from the Mekhilta de-Rabbi Yishmael, Beshalah: "This refers to the war of the sons of Ephraim, as it is said, 'And the sons of Ephraim: Shuthelah—and Bered was his son ... whom the men of Gath that were born in the land slew' (1 Chron. 7:20-21) — two hundred thousand children of Ephraim. And it also says: 'The children of Ephraim were archers, handling the bow, they turned back in the day of battle' (Ps. 78:9). Why? Because 'they keep not the covenant of God and refused to walk in his law' (78:10), that is because they ignored the stipulated term, because they violated the oath."

21. Esther Rabbah 1.

22. In his commentary on this verse, Rashi, justifiably, identifies the 7,000 that were left in the Ahab's army during his war with Ben-hadad with the 7,000 mentioned in the prophecy that Elijah received on Mount Horeb.

23. For further information on these findings, see: Hayim Tadmor, Asshur, Bavel ve-Yehudah: Mekharim be-Toldot Ha-Mizrah Ha-Kadum [Assyria, Babylonia, and Judah: Studies in the history of the ancient Near East] (Jerusalem: Mosad Bialik, 2006), 1-2.

24. The deciphering was done primarily by A. K. Grayson in Canada and Riekele Borger and his students in Germany.

25. See William W. Hallo, "Mesopotamia," in Entzeklopedia Mikrait [Encyclopaedia biblica] (Jerusalem: Mosad Bialik, 1968), 5:59-130 (esp. page 90); A. Malamat, "Milhamot Yisrael ve-Ashur" [The wars between Israel and Assyria], in Ha-Historia Ha-Tzva'it shel Eretz Yisrael Be-Yimei Ha-Mikra [The military history of Israel in the time of the Bible], ed. Jacob Liver (Tel Aviv: Maarachot, 1964), 241-260, esp. 246-247. It is possible that partial invasions in remote areas occurred in the time of Jehu.

26. I heard a similar explanation from my revered teacher Rabbi Yoel Bin Nun, upon which my arguments here are based.

27. This is the interpretation of Radak (Rabbi David Kimhi).

28. This is the interpretation of Radak and Ralbag (Gersonides) on this verse. Rashi, following the midrash, explains that according to the Torah itself the prohibition is to be lifted in the case of a war against Moab or Ammon.

29. "The Moabite Stone," in W. F. Albright, "Palestinian Inscriptions," in Ancient Near Eastern Texts, ed. James B. Pritchard (Princeton: Princeton University Press, 1969), 320.

30. Yehudah Elitzur analyzed the proclamation of Moab along the lines presented here. I have expressed my thoughts here in a slightly different manner. His ideas are seminal and should be read in the original. See Yehuda Elitzur, "Masa Moav u-Ketovet Mesha" [The proclamation of Moab and the Mesha Stele], in Yisrael ve-ha-Mikra: Mehkarim Geografi'im, Histori' im u-Haguti'im [Israel and the Bible: Geographic, historical, and philosophical studies], ed. Yoel Elitzur and Amos Frisch (Ramat Gan: Bar Ilan University, 1999), 175-182. 